QA: N/A

Civilian Radioactive Waste Management System

Management \& Operating Contractor

\title{
MONITORED GEOLOGIC REPOSITORY \\ LIFE CYCLE COST ESTIMATE ASSUMPTIONS DOCUMENT
}

MIS-MGR-AD-000002 REV. 00

February 2000

Prepared for:

U.S. Department of Energy

Yucca Mountain Site Characterization Office P.O. Box 30307

North Las Vegas, NV 89036-0307

Prepared by:

TRW Environmental Safety Systems Inc.

1180 Town Center Drive

Las Vegas, Nevada 89134

Under Contract Number

DE-AC08-91RW00134 
Civilian Radioactive Waste Management System

Management \& Operating Contractor

\section{MONITORED GEOLOGIC REPOSITORY \\ LIFE CYCLE COST ESTIMATE \\ ASSUMPTIONS DOCUMENT}

MIS-MGR-AD-000002 REV:00

February 2000

Prepared by:
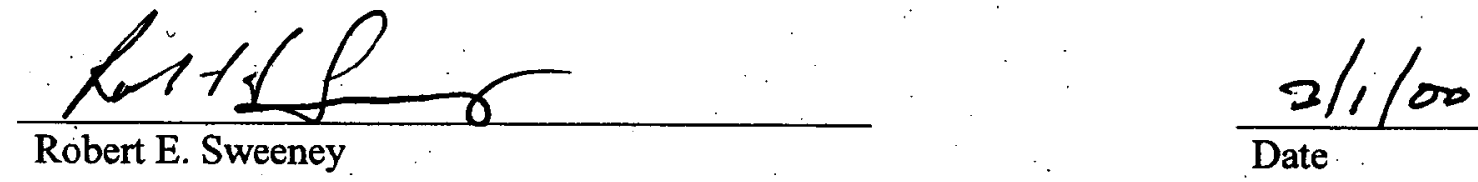

Reviewed by:
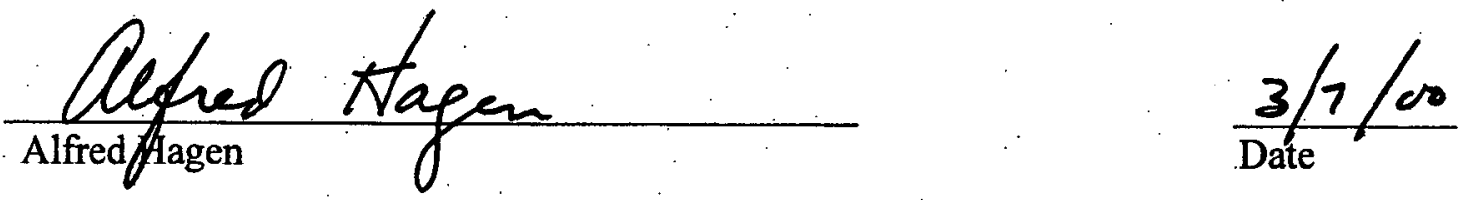

Approved by:

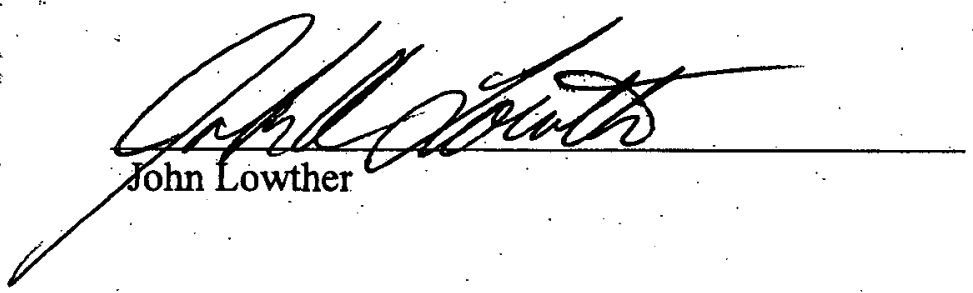




\section{DISCLAIMER}

This report was prepared as an account of work sponsored by an agency of the United States Government. Neither the United States Government nor any agency thereof, nor any of their employees, nor any of their contractors, subcontractors or their employees, makes any warranty, express or implied, or assumes any legal liability or responsibility for the accuracy, completeness, or any third party's use or the results of such use of any information, apparatus, product, or process disclosed, or represents that its use would not infringe privately owned rights. Reference herein to any specific commercial product, process, or service by trade name, trademark, manufacturer, or otherwise, does not necessarily constitute or imply its endorsement, recommendation, or favoring by the United States Government or any agency thereof or its contractors or subcontractors. The views and opinions of authors expressed herein do not necessarily state or reflect those of the United States Government or any agency thereof. 


\section{CONTENTS}

1.0 PURPOSE 1

2.0 SCOPE 1

3.0 PLAN ELEMENTS, MILESTONES AND PHASES 1

3.1 Plan Elements 1

3.1.1 Regulatory, Infrastructure and Management Support 1

3.1.2 Surface Facilities $\quad 2$

3.1.3 Subsurface Facilities $\quad 2$

3.1.4 Waste Package 3

3.1.5 Nevada Transportation 3

3.1.6 Performance Confirmation 3

3.1.7 Off-site Utilities and Physical Infrastructure 3

3.2 Milestones and Phases 3

3.2.1 Milestones 4

3.2.2 Monitored Geologic Repository Project Phases 4

$\begin{array}{lll}4.0 & \text { ASSUMPTIONS } & 6\end{array}$

4.1 General Assumptions 6

$\begin{array}{lr}\text { 4.2 Element Specific Assumptions } & 8\end{array}$

4.2.1 Regulatory, Infrastructure and Management Support $\quad 8$

$\begin{array}{ll}\text { 4.2.2 Surface Facilities } & 10\end{array}$

$\begin{array}{ll}\text { 4.2.3 Subsurface Facilities } & 10\end{array}$

4.2.4 Waste Package 11

$\begin{array}{ll}4.2 .5 \text { Nevada Transportation } & 12\end{array}$

4.2.6 Performance Confirmation $\quad 13$

4.2.7 Off-site Utilities and Physical Infrastructure 14

$\begin{array}{lll}5.0 & \text { REFERENCES } & 15\end{array}$ 


\subsection{PURPOSE}

The purpose of this assumptions document is to provide general scope, strategy, technical basis, schedule and cost assumptions for the Monitored Geologic Repository (MGR) life cycle cost estimate and schedule update incorporating information from the Viability Assessment (VA), License Application Design Selection (LADS), 1999 Update to the Total System Life Cycle Cost (TSLCC) estimate and from other related and updated information. This document is intended to generally follow the assumptions outlined in the previous MGR cost estimates and as further prescribed by DOE guidance.

\subsection{SCOPE}

The MGR life cycle cost (LCC) represents the repository schedules and costs reflecting the reference design, commencing with Fiscal Year 2000 through decommissioning in 2072. Submittal of the License Application (LA) in August 2002 is required. This period includes completion of the EIS and SR activities, design, licensing, construction, and startup testing operations of the baseline repository. Use of an engineering, procurement and construction structure for each discrete product will also be a major focus of the plan. Where assumptions were made affecting competitive strategies, funding schedules and profiles in order to meet government funding guidelines, and activities affecting long-lead procurement activities and critical paths, they are noted. The cost figures and supporting assumptions are primarily derived from the MGR cost estimate and schedules prepared for the VA, LA10 and LADS efforts. This document and the resultant MGR schedule will supersede previous schedules developed in FY 99 under other initiatives.

\subsection{PLAN ELEMENTS, MILESTONES AND PHASES}

\subsection{Plan Elements}

The MGR schedule shall be based upon discrete, defined major elements. These major elements and sub-elements are listed below.

\subsubsection{Regulatory, Infrastructure and Management Support}

This element will consist of a variety of repository support services not included in other cost estimates. These services will include operational support, management and administration systems under the following sub-elements:

- Regulatory

- Pre-CA Site Services

- Environment, Safety and Health

- Infrastructure

- Training

- Set Asides

- Monitoring Technical Assistance 


\subsubsection{Surface Facilities}

This element will include the work relating to surface facilities' design, procurement, construction, testing, training, operations and decommissioning. It will include the following sub-elements and associated activities under waste handling systems and operational support systems:

- Site Preparation

- Temporary Facilities

- Radiological Controlled Common Area

- Balance of Plant Common Area

- Waste Handling Building

- Waste Treatment Building

- Carrier Preparations Building

- Transporter Maintenance Building

- Airlock Building

- Administration Building

- Pump Houses

- Security Stations

- Fire/Medical Building

- Warehouses

- Mock-up Building

- Utility Building

- Visitor's Center

- Service Station

\subsubsection{Subsurface Facilities}

This element will include the work relating to design, procurement, construction, testing and startup, long term monitoring, closure and decommissioning. It will include waste handling systems, waste isolation systems and operational support systems under the following subelements:

- Temporary Subsurface Facilities

- South Portal

- Panel No. 1

- Panel No. 2

- Panel No. 3

- Panel No. 4

- Panel No. 5 


\subsubsection{Waste Package}

This element will include the work relating to design, procurement, fabrication and testing of the disposal containers, drip shields and waste package supports.

- Commercial Spent Nuclear Fuel Containers

- Defense High-Level Radioactive Waste Containers

- DOE Spent Nuclear Fuel Containers

- Waste Package Structural Supports

- Drip shield

\subsubsection{Nevada Transportation}

This element will consist of the transportation and rail systems within the state up to the repository. These support services will include the following sub-elements:

- Nevada Railways

- Nevada Roadways

- Operational Systems and Support Services

\subsubsection{Performance Confirmation}

This element will include the work within the scope of the Performance Confirmation (PC) program. It will include waste isolation and PC systems under the following sub-elements:

- Post-closure Evaluation System

- Process Monitoring system

- Operational Support

- License Application Testing

\subsubsection{Off-Site Utilities and Physical Infrastructure}

This element will consist of a variety of repository utility and infrastructure support and services not included in other cost estimates. These support services will include the following subelements:

- Infrastructure and Support Systems

- Utility Systems

\subsection{Milestones and Phases}

The major milestone dates and project phases to be used in the MGR schedule are below. 


\subsubsection{Milestones}

The schedule contains the project activities required to meet key project milestones. The annual estimated costs reflect the schedule for which activities will be performed.

Milestone

Submit Site Recommendation to President

Submit License Application for Construction Authorization

Start Repository Construction

Start Waste Emplacement

Complete Emplacement

Start Repository Closure \& Decommissioning

Complete Repository Closure \& Decommissioning
Date

July 2001

August 2002

September 2005

October 2010

September 2040

October 2066

September 2072

\subsubsection{Monitored Geologic Repository Project Phases}

The time period encompasses work to be performed as prescribed by SR design. The MGR schedule extends through several project phases from fiscal year 2000 through 2072. During this period, the project will evolve as further described below.

\section{- Site Characterization: September 1999 to July 2001}

This phase covers the current scope of activities to support Site Characterization. It is assumed complete when the Secretary decides to recommend approval of the site, and PC activities required by NRC licensing criteria, and other testing, follow the Secretary's decision and continues until the end of the monitoring period.

\section{- Site Selection Review: August 2001 to August, 2002}

This phase includes all activities and costs related to continued assessment of site characterization data and reviews associated with SR and the Environmental Impact Statement (EIS), as well as final selection of the repository design details and features and the preparation of the LA.

\section{- Licensing Review: September 2002 to August 2005}

This phase includes all activities and costs related to completion of the repository and wastepackage designs. It will also include activities and costs to support the LA and respond to any EIS issues. The schedule also contains the costs to develop test requirements for facility operating systems and the monitoring systems that will confirm repository performance, as well as include some designated construction activities that are temporary in nature which can be performed prior to issuance of the Construction Authorization. 


\section{- Construction and Testing: September 2005 to September 2010}

The Construction and Testing Phase starts after the NRC authorizes construction and includes all capital and operating costs to construct surface and subsurface facilities at the site and within the radiological controlled area. The underground area will include, as a minimum, sufficient completion to be ready to begin emplacing waste packages in October 2010. Activities and costs include expenses for additional design and licensing work, personnel training, prototype testing, developing operating and maintenance procedures, repository startup operations, and establishing baseline parameters for confirming repository performance. The initial procurement of disposal containers will take place during this phase in order to support emplacement operations.

This phase includes execution of Title I and II design, and initial construction under Title III, guided by the project's approved baseline and planning documentation. As the project progresses from its preliminary design into a detailed (definitive) design, a series of design reviews are anticipated during each stage of design to assess progress to the baseline. In addition, this phase will to ensure that technical performance is demonstrated and verified according to the project's baseline, functional requirements, and mission need objectives. During this phase the project manager will also assure that validation and verification, benchmark tests, and operational readiness reviews and/or assessments are performed in accordance with project plans and standards.

\section{- Emplacement Operations Phase: October 2010 to September 2040}

The Emplacement Operations Phase begins after the NRC issues a license amendment for the repository to receive and possess waste. Based upon current schedule, it is assumed to take approximately 30 years to emplacement all 97,400 MTHM. The major cost elements for this phase includes repository operations for accepting the waste, and the procurement, handling, and emplacement of waste packages. Also included will be the capital and operating costs for continued underground construction, startup activities, and the cost of tests and analyses required to confirm the repository's performance.

\section{- Monitoring Phase: October 2040 to September 2066}

The Monitoring Phase includes capital and operating costs to decontaminate and mothball most of the surface facility structures and systems. Cost elements also cover expenses for maintaining the facilities in stand-by status and providing sufficient maintenance to retrieve waste packages, if necessary. Costs associated with the ventilation and inspection of the underground access and main drifts will continue, as will performance confirmation and required security functions.

\section{- Closure and Decommissioning Phase: October 2066 - September 2072}

The Closure and Decommissioning Phase includes operating and capital costs for demolishing the repository surface infrastructure; emplacement of drip shields; constructing barriers to 
preclude human intrusion; backfilling the access shafts, ramps and boreholes; and restoring the site to a condition that does not require human support.

\subsection{ASSUMPTIONS}

The costs and schedules for the MGR will be based on a set of assumptions during the time phases noted above. The assumptions -- primarily derived from the VA, Volumes 4 \& 5, LA10 Updates, and LADS -- have been reviewed and adjusted to provide an appropriate basis for the MGR life cycle cost (LCC) estimate and are consistent with the proposed SR design and baseline. The cost figures will be only as valid as the assumptions, and if the assumptions are changed, the integrity of the cost and schedule must be reconfirmed.

\subsection{General Assumptions}

The following general assumptions are for the MGR updated schedule and cost summary include:

- The Yucca Mountain site is recommended and approved for development as a repository based upon the concepts of the current SR reference design and subsequent related efforts.

- All associated estimated costs are in constant 2000 dollars. Where costs are escalated from earlier dollars, an escalation factor based upon DOE approved escalation rates will be used to convert to 2000 dollars.

- The costs and schedules are reflected in fiscal years.

- Operations and Maintenance (O\&M) costs associated with the activities required to maintain the effectiveness of response actions will be considered in the life-cycle costs.

All other costs will be assumed as capital costs in accordance with DOE and OMB guidelines.

- The repository schedules or costs do not address or accommodate a capacity for the repository beyond the 83,800 MTHM commercial spent nuclear fuel (SNF).

- Repository and Waste Package Designs will accommodate waste allocations as follows:

- 83,800 MTHM commercial spent nuclear fuel

- 2,500 MTHM DOE spent nuclear fuel including naval spent nuclear fuel

- 22,200 Canisters of Defense HLW

- Repository plans only include disposal of SNF or HLW that is not subject to regulation as hazardous waste under the Resource Conservation and Recovery Act (RCRA) Subtitle C.

- Activities are planned consistent with the project's execution of activities to meet NRC proposed 10 CFR Part 63 requirements, currently issued for public comment.

- A performance based management and operating (M\&O) contract is assumed to be issued prior to SR to plan, manage, and integrate all activities supporting both unique and nonunique functions for the OCRWM program in the most cost effective manner. The resultant contract will be a performance based $M \& O$ contract for a five-year period (plus 
a three-month transition period) with a unilateral extension option, at the Government's discretion, for up to an additional five year period.

- The M\&O contractor, and/or its successor, is assumed to manage the design, licensing and construction related programs up to the beginning of emplacement. At that time, it is contemplated that an operations type contractor will be selected and responsible for concurrent operations and construction management activities.

- It is assumed that DOE will continue to lease office space in LV, and the M\&O will continue as well, gradually shifting resources to the site to support construction, startup and ultimate commissioning. By the beginning of emplacement operations, the M\&O and successor operations contractor are assumed to be almost entirely located at the site, with some limited presence off-site, and possibly in LV. During the design and construction periods of the project, there will be some home office contractor support; however, any resources are considered phased out without impacting LV or YMP office requirements.

- Based upon the OCRWM developed Enterprise Architecture, a strategic information asset base will be assumed to support program business and information technologies (IT) needs during program operations and related transitional processes for implementing new technologies over the life cycle of the repository and OCRWM programs.

- Construction activities that are temporary in nature can be performed prior to issuance of the CA.

- Based on experience gained from activities performed during the pre-construction phase of DOE and commercial nuclear facilities, as well as reliance on NRC concurrence of a non-nuclear pre-construction site development plan, options are assumed for preconstruction authorization, including allowances and provisions for early procurement of long-lead items prior to CA scheduled for September 2005.

- Construction under the M\&O concept will assume that any support operations and facilities will be part of the contracting requirements for the specific area, building, etc. for which that contractor(s) is responsible. The contractor is assumed to be responsible for supplying any related maintenance, supplies, or service personnel in conjunction with its contract deliverables. Any significant site-wide, shared support facilities will be identified in a specific contractor work element.

- To accommodate fast track and parallel construction activities, multiple contractors working or overlapping simultaneously will be assumed, such that work rates and safety management are not compromised.

- Repository design, construction and initial emplacement of waste will be conducted under a quality assurance program as described in the current Quality Assurance Requirements and Description (DOE 1998).

- There is no requirement for additional planned site characterization or collection of further data in potential repository expansion areas. However, further geo-technical and seismic data is required to support surface facility design, e.g., WHB footprint.

- The pre-construction site test facilities will become part of the final repository layout. They may be upgraded, as required, and construction may be performed prior to Construction Authorization. 
- DOE will own and control land, water rights, and subsurface rights. After a site recommendation is submitted to Congress, and final Congressional action is taken, DOE will formally dedicate the land for constructing a repository.

- Substantially complete construction of repository facilities will be required for the initial receipt and possession of spent nuclear fuel and high-level radioactive waste. Substantially complete construction is defined as completion of the surface facilities and sufficient construction of emplacement drifts to safely handle and emplace the initial waste packages.

- DOE Operational Readiness Reviews will rely on the site visits, inspections, audits and surveillances from the NRC and other regulatory agencies, prior to emplacement authorization.

- All spent nuclear fuel and high level waste will be shipped to the repository. Most commercial spent nuclear fuel will be transported by rail directly from the utility. No interim storage or co-located interim storage at the repository is considered.

- There are no requirements identified at this time for a prototype facility.

- Design will be for approximately 5,000 MTHM of in-process retention to support thermal blending of CSNF. Design does not accommodate any onsite storage of canistered fuel.

- Repository design and facility operations planning will be compatible with transportation of SNF and HLW to the repository by rail, heavy haul vehicle, and legal weight truck, and as further delineated in the program requirement documents.

- The MGR design and planning maintain flexibility by considering pending changes to applicable NRC repository licensing regulations and the Environmental Protection Agency (EPA) radiation protection standards. Cost impacts resulting from possible schedule delays or other actions beyond the control of YMP will not be included.

- Current cost-sharing and support arrangements with the Nevada Test Site will continue as needed. A memorandum of understanding (MOU) revision will be developed later to refine scope and responsibilities.

- LLW will be packaged, dispositioned and/or disposed at the Nevada Test Site, under a rate structure consistent with a commercial service.

- All permanent equipment will be purchased by the contractor and therefore subject to the contractor's overhead, profit, and bond; no equipment will be furnished by DOE.

- Repository construction and pre-emplacement operations organizations will interface with appropriate federal, state, tribal, and local government agencies to meet legal, regulatory and operational requirements for emplacement and isolation of waste, such as scheduling, permitting, notifications, emergency planning and response, and security.

- Pursuant to the Nuclear Waste Policy Act as Amended, (1987) Payment Equal To Taxes (PETT), Financial and Technical Assistance (F\&TA) and other benefits as defined by the NWPA will continue to be planned and costed.

\subsection{Element Specific Assumptions}

The following are preliminary assumptions specific to each of the major elements for the project phases included in the plan, and they address topics to be considered affecting the cost. (The assumptions will be expanded upon or modified, and documented in detailed backup sheets. It is expected that each lead review and modify assumptions as necessary and note where assumptions 
for the MGR vary from those used in the VA, e.g. some may not apply for the period or phases of the MGR. Additionally, emphasis of the key assumptions noted herein should be placed on "planning" assumptions as well as those used to develop the cost).

\subsubsection{Regulatory, Infrastructure and Management Support}

- Continued emphasis of TSPA studies abstraction and testing and sensitivity analyses to support regulatory activities will continue on the following process models: unsaturated zone hydrology, saturated zone hydrology, unsaturated zone and saturated zone transport, thermal hydrology, waste package degradation, coupled process models, and waste form mobilization.

- Testing to support license application will be estimated based upon data needs identified via analysis and process model reports (AMR/PMR) to support the licensing argument and to support authorization to receive and possess waste. Testing as specified by the NRC during licensing negotiations will also be estimated. TSPA updates will focus on improving models in previously identified areas necessary to support the licensing arguments (a blanket model improvement program is not proposed).

- Continued interaction with the NRC on licensing amendments to possess and emplace waste and other regulatory issues will be required.

- Operation and maintenance costs for the underground pre-construction test facility will be covered in the Regulatory, Infrastructure, and Management Support estimate for 2002 to 2005, after which the Subsurface Facilities cost estimate will assume the scope and budget.

- Site surface logistical support will be covered in the RIMS through fiscal year 2001, after which the surface and subsurface facilities will assume scope and budget in support of their respective field and construction operational requirements.

- No substantial change in proposed actions or significant new information is assumed that could require a new EIS. Cost estimates will include costs associated with supporting an EIS supplement, if necessary.

- Regulatory, infrastructure, and management support cost estimates will contain Environment, Safety and Health work activities between 2002-2010. After October 2010, costs associated with these activities will be included in the estimate for operation of the surface facilities.

- The current M\&O type contracting for design, licensing and construction support will be phased out and an operations type contractor will be phased in to support facility transitions in late 2010. At that time, it is also contemplated that a construction management type contractor will direct the concurrent construction activities required during the emplacement phase.

- No information management support will be provided to performance confirmation in the areas of technical data management or performance assessment. Performance Confirmation will provide its own support in these areas.

- Computer hardware and software upgrades will be assumed to occur every 36 months with one-third of the upgrade occurring each year.

- Training of nuclear operators will be excluded from the RIMS Training estimate. Costs for initial and update training of operators will be included in the surface operations cost 
estimate.

- Support to DOE by the management technical support contractor will be maintained through 2010 and beyond through emplacement. The level of effort to support the DOE will vary over the different phases commensurate with the type of work and intensity of design, licensing ,construction and operational activities.

- Overhead costs and project award fees will be included in the Regulatory, Infrastructure and Management Support cost estimate for all project cost elements.

\subsubsection{Surface Facilities}

- Construction crews will consist of one foreman and five craft workers. Construction staff working swing and graveyard shifts work 7 hours a day and will be paid for 8 hours.

- Construction labor rates will be based on craft rate data from the Nevada Test Site's 1997-2002 labor agreements.

- Design costs to support construction will be estimated as a percentage of total field costs without contingency. Surface facility design activities will continue through the construction period, up to October, 2009.

- Construction of facilities will be completed in advance of emplacement operations with sufficient time to ensure pre-operational testing and training is completed to support turnover to DOE and the necessary DOE and regulatory agency inspections and acceptance reviews. Start-up preparation activities, e.g., procedures, training, etc., are assumed to begin approximately 3.5 years in advance to emplacement.

- Operations staff will work 1,856 hours annually, including training hours. All employees will require 8 hours of general employee training. Nuclear workers will require additional training; and any staff that perform safety functions will require additional training.

- Waste handling, security, and associated support operations will be planned for three shifts per day, 7 days per week, 50 weeks a year. Other operations will be planned for a single shift and 5 days per week. Operations staff working the swing and graveyard shifts will be paid shift differentials. Facility operation is planned for approximately 6,000 hours per year.

- Construction management costs will be estimated as a percentage of total direct and indirect field costs and subcontracts, without contingency.

- Major surface facilities will be constructed on a competitive contract basis maximizing the use of lump sum type contracts, and any major equipment needed by the contractor to support the scope of work will be provided by the contractor.

- The cost of operating supplies will be a percentage of the operations and labor cost and include materials such as decontamination and water-treating chemicals, inerting gases, offices supplies, and janitorial supplies.

- Annual maintenance materials costs will be estimated as percentages of the non-labor portion of the direct field costs without contingency. Maintenance materials costs will not be included for the site work and concrete accounts.

- Indirect field cost will be estimated from direct field cost data (i.e., costs for labor, materials, equipment, and subcontracts). 
- The cost of the initial spare parts will be estimated as a percent of the maintenance materials cost for an average emplacement year.

- Design support will be required during operational phase and support maintenance and modifications.

- Training for operations staff will include maintenance and surveillance training to maintain and operate the facility and equipment.

\subsubsection{Subsurface Facilities}

- The layout will be similar to the EDA Alternate II with additional emplacement drifts to the south allow for the additional waste.

- The ventilation rate will be $15 \mathrm{cms}$ to allow of cooling. There will be 10 to 12 ventilation shafts to handle the volume of ventilation air required.

- The north end of the repository will developed to allow for the emplacement of waste to begin starting in late 2010, and to provide space while the access and ventilation drifts are developed after the 2010 start.

- The access and ventilation mains will be 7.62 meters in diameter with a cast in place concrete lining. The emplacement drifts will be 5.5 meters in diameter.

- Ground support will be grouted rock bolts and wire mesh, supplemented with steel sets, as needed.

- The North Portal will be congested because of the surface facility construction, so the subsurface access will be from the South Portal. The area will be graded to provide a place for the Subsurface Construction Support Facilities.

- The muck disposal belt will exit from the South Portal. The surface facilities at the South Portal are all required to support the subsurface operations so they have been include in the subsurface scope of work.

- The subsurface estimate includes surface water control in the vicinity of the South Portal Site Work and the Muck Disposal Piles.

- The scope of the South Portal Facilities includes underground utilities, a substation, an office, shop facilities, warehouse facilities, and a change house.

- A batch plant and pre-cast yard will be located near the South Portal area to minimize transportation distances and re-handling.

- The repository will have airtight bulkheads to separate emplacement operations from the North Portal from the construction operations with access from the South Portal.

- During closure a crushing and screening plant will be required in the South Portal Area.

- The emplacement operation will receive the waste package from a loading dock at the surface processing plant. The waste package will be transported using a special rail and specialized locomotives. The waste packages will be transferred into the emplacement drifts using a remote controlled gantry crane.

- Support for the development of remotely operated vehicles and equipment for Performance Confirmation activities will be covered by subsurface activities.

- The Labor Rates for Craft Labor will be based upon the current Union Labor Contracts at the site or as otherwise provided and documented.

\subsubsection{Waste Package}


- Waste packages will be designed and fabricated in advance to begin emplacement of 400 MTHM in the first year at the repository and to receive annual waste shipments up to a peak rate of 3,000 MTHM commercial SNF, and 700 canisters of combined DOE SNF and Defense High Level Waste.

- The waste package outer and inner barriers will be in accordance with LADS EDA II.

- Waste Package fabrication organization will continue to procure prototypes and mockups. Methods and processes for procuring mock ups, prototypes and associated other direct costs items to continue the weld and NDE development work will not change from current expectations.

- Borated stainless steel plates will be used for criticality control where needed.

- The waste package will be fabricated and inspected in accordance with the American Society of Mechanical Engineers Code, Sections III and any section referred to by Section III, but will not be $\mathrm{N}$ stamped. The vessel will not be $\mathrm{N}$ stamped because it is not a pressure vessel.

- Prototype, mockup and dummy cask testing will be performed to support waste package design, construction, test and evaluation activities.

- Labor rates will be based upon information obtained from acceptable sources, and considered fully burdened.

- The other category, used with a standard $20 \%$ adder, will be considered to be overhead costs consisting of equipment, office temporary facilities, supplies, etc., as well as charges for administration and profit.

- The NRC will require prototype tests to validate the engineering analyses and models even though 10 CFR 63 does not contain specific criteria that requires a waste package prototype.

- Waste Package prototypes are full scale and have the same geometry as the production Waste Packages.

- Waste Package welding mock-ups are full scale diameter but short length.

- Waste Packages for a pre-operational test program of waste handling systems will have the same external geometry as the production Waste Packages with internals to simulate the proper weight distribution.

- The "component testing" of Waste Packages prototypes will be destructive.

- A remote welding system will be developed and tested.

- Just-in time delivery is considered with a week supply of disposal containers on site.

\subsubsection{Nevada Transportation}

- Rail will be available for transporting waste to the repository at the start of emplacement operations. Rail is the "reference case" for project planning.

- Repository design and facility operations planning will be compatible with transportation of SNF and HLW to the repository by rail, limited heavy haul vehicle, and legal weight truck.

- The public comment period for NEPA review is on the order of 60 days. 
- Related NEPA and design activities are to be performed by the M\&O contractor. Rail construction will sub-contracted via competitive solicitation via requests for proposals. A short-line rail operator will be contracted by DOE to perform O\&M tasks.

- A mode and route designation study is required. A decision must be made after SR; however, the final design can start prior to route designation.

- A new site access road will be available for start of repository construction, and it will be located on the west side adjacent to 40 Mile Wash. The schedule to design and construct the site access road is $\mathbf{2 8}$ months. Construction time estimate is approximately 10 months.

- Preliminary design cannot be completed until the completion of the draft NEPA document. Preliminary Design will develop all options and alternates equally. Final design will drop all options and alternates and assume a single alignment.

- Engineering and procurement for all 5 routes options are assumed to have the same duration.

- Construction RFPs are assumed to start 2 months before completion of final rail design. Construction cannot start until all BLM land is obtained; however, it can start with some, but not necessarily all, private land purchased. Land acquisition activities will be the same duration for all 5 rail routes. In any event, rail construction would not start before CA.

- Construction time for the Caliente route is same as Carlin route, and construction time for the Jean route is same as Caliente/Chalk Mountain route.

- Constrained funding scenarios are not assumed for Nevada transportation activities.

\subsubsection{Performance Confirmation}

- Excavation equipment will be limited for PC activities, requiring sequential excavation of different $\mathrm{PC}$ alcove facilities.

- Due to conflicts with initial excavation activities near the South Portal, Performance Confirmation seal and backfill facilities will not be excavated until after 2010 .

- The PC element will be limited to post-emplacement estimates for the post-closure simulation tests and the process confirmation tests, and those resources necessary to support those tests.

- Seals testing will be estimated under subsurface and will not be estimated under the PC element.

- In situ backfill and drip shield testing will be performed in conjunction with the postclosure simulation test.

- Waste packages to support PC tests are selected from the fabrication stream. Therefore, they are identical to waste packages for emplacement purposes. Only the cost of the waste packages are included in the estimates for this PC activity. The procurement order quantity would be increased to cover the needed quantity of test assets.

- Materials specimens will be prepared from material samples supplied with the fabricated waste packages. The preparation of material specimens will be a procurement of that service similar to the current procurement process for material specimens.

- Information management support and TSPA updates will be estimated to support PC activities. Performance assessment and technical expertise resources will be assumed 
available only when needed. Core staff on hand throughout the monitoring phase will be kept to a minimum.

- Excavation activities and associated costs under PC Subsurface Facilities in the Viability Assessment have been transferred to the subsurface construction activities and costs.

- Excavation of PC Observation Drifts will begin after ramp upgrade activities.

- Subsurface activities will design the excavations for PC test programs. PC plan and design activities will determine bore-hole and instrument placement and layouts.

- The development of Remotely Operated Vehicles (ROVs) for PC work is performed under other subsurface activities.

- Special test alcoves and niches for seismic monitoring and seepage monitoring, located along access mains, are excavated as soon as possible after construction of the attendant accessway to minimize disturbance.

- The first emplacement observation drift and attendant alcoves are excavated and completed two years prior to the start of emplacement to allow for instrumentation installation and baseline development prior to the start of emplacement.

- Construction of emplacement drift observation facilities (other than the first observation drift) are completed two years prior to the construction of emplacement drifts in the respective test areas to allow for the monitoring of construction-induced effects.

- Surface-based monitoring wells for evaluating water quality around the emplacement horizon are constructed and completed at least one year prior to the start of emplacement to establish a sufficient data baseline.

- A full-time core staff will provide continuity of test activities during the different phases of the repository. Participation from outside organizations will be minimal. The core staff will consist of the minimum number of people needed to process, analyze, evaluate and report test data.

- Technical expertise is assumed to be provided by National Laboratories, if available, for activities traditionally supplied by the laboratories, provided that their rates are competitive with commercial entities or other third parties having comparable expertise.

\subsubsection{Off-Site Utilities and Physical Infrastructure}

- In order to minimize potential budget and schedule impacts, it will be assumed that the cost of a new electric power line, having the capacity to support the necessary construction and operational loads at the site, will be amortized over the life of the construction program (or approximately 30 years and included in future YMP electric rates).

- Prior to construction authorization and commissioning of the new line, electricity to YMP will continue to be provided by the NTS.

- Utility work necessary to support meeting electrical requirements for construction phase activities will be completed in advance of CA.

- Water permits will be obtained for extended usage needs. 


\subsection{REFERENCES}

DOE 1998_Viability Assessment of a Repository at Yucca Mountain. DOE/RW-0508, December 1998. Washington, D.C.: U.S. Government Printing Office. Overview, MOL.19981007.0027; Vol. 1, MOL.19981007.0028; Vol. 2, MOL.19981007.0029; Vol. 3, MOL.19981007.0030; Vol. 4, MOL.19981007.0031; Vol. 5, MOL.19981007.0032.

DOE 1998_. Analysis of the Total System Life Cycle Cost of the Civilian Radioactive Waste Management Program. DOE/RW-0510, December 1998. Washington, D.C.: U.S. Department of Energy, Office of Civilian Radioactive Waste Management. HQO. 19980901.0001

DOE 1999_. "DRAFT" Analysis of the Total System Life Cycle Cost of the Civilian Radioactive Waste Management Program. September 1999. Washington, D.C.: U.S. Department of Energy, Office of Civilian Radioactive Waste Management

Monitored Geologic Repository Cost Estimate Assumptions, September 1998. DI: B0000000001717-2200-00205 REV. 01

Civilian Radioactive Waste Management System Requirements Document, January 1999. DI: A00000000-0081 1-1708-00003 REV 05

DOE 1998c. Quality Assurance Requirements and Description (QARD). DOE/RW-0333P, REV 8, June 1998. Washington, D. C.: U.S. Department of Energy, Office of Civilian Radioactive Waste Management. MOL.19980601.0022.

10 CFR 63, Draft Proposed Rule. 1998

Nuclear Waste Policy Act of 1982. Public Law 97-425, 42 U.S.C. 10101-10226. 1983. TIC 216801.

Amendments to the Nuclear Waste Policy Act of 1982. Public Law 100-203, December 27, 1987, 100th Congress, Title V. TIC 222510. 